\title{
DESAIN PRIMER PCR SECARA IN SILICO UNTUK AMPLIFIKASI GEN COI PADA KUPU-KUPU Papilio ulysses Linnaeus DARI PULAU BACAN
}

\author{
Suparman $^{1}$, Hasna Ahmad ${ }^{2}$, Zulkifli Ahmad ${ }^{2}$ \\ ${ }^{1}$ Laboratorium Biologi FKIP Universitas Khairun-Ternate \\ ${ }^{2}$ Program Studi Pendidikan Biologi FKIP Universitas Khairun-Ternate \\ Email: suparman_bio@yahoo.com
}

\begin{abstract}
The insillico research was conducted to produce primer sequence of COI gene in Butterfly species Papilio ulyses from Bacan Island that will be used in gene isolation. The COI sub-unit I is a barcode gene that generally have special purposes in animal identification. It is also available in phyilogenetic analysis. The first step of method is downloading the COI DNA sequence of Papilio ulysses from GeneBank (NCBI). Then the conserve region of COI sequence is identified to determine primer. Primer is designed with primer designer software (Genamics Expression) in two direction of DNA reading frame that are : forward primer (COI Pu-F) and reverse primer (COI Pu-R). The last step is primer confirmation with primer blast tool in NCBI. Primers of COI gene that are produced consist of two, that are CGAAAATGACTTTATTCAACA for forward primer (COI Pu-R) and AGCAGTAATTCCAACAGCTC for reverse primer (COI Pu-R). The optimal temperature of annealing is from $50,74^{\circ}$ to $55,74^{0}$ Celsius with PCR product around 567 base pair long.

Key Words : PCR primer, in silico, COI gene, Papilio ulysses, Bacan island.
\end{abstract}

Indonesia merupakan negara yang memiliki sumber kekayaan dan keanekargamana hayati yang tinggi. Keanekaragamana hayati tersebut terdapat hampir disemua provinsi. Provinsi Maluku Utara salah satu provinsi dengan karagaman hayati yang tinggi baik dari tumbuhan maupun hewan. Keanekaragaman tersebut berada dalam berbagai jenis ekosistem yang tersebar di banyak pulau besar maupun kecil. Saat ini, Provinsi Maluku Utara secara administratif, terbagi dalam
Kabupaten/Kota yang terdiri dari Kota Ternate (Ternate), Kota Tidore Kepulauan (Soa Sio), Kabupaten Halmahera Barat (Jailolo), Kabupaten Halmahera Timur (Maba), Kabupaten Halmahera Utara (Tobleo), Kabupaten Halmahera Selatan (Bacan), Kabupaten Kepulauan Sula (Sanana), Kabupaten Pulau Morotai (Morotai), dan Kabupaten Taliabu. Salah satu Kabupaten yakni Halmahera Selatan memiliki ekosistem yang beragam baik pantai, hutan, maupun gunung. Selama ini 
pendataan dan kegiatan eksplorasi flora dan fauna di kabupaten tersebut belum dilakukan secara komprehensif dan intensif. Di salah satu pulau terbesar, yakni Pulau Bacan terdapat kawasan Cagar Alam Gunung Sibela dengan luas \pm 23.024 ha (BPS Halmahera Selatan, 2015) yang memiliki keanekaragaman jenis flora dan fauna cukup tinggi (Ahmad et al., 2015). Potensi sumberdaya alam yang terdapat di kawasan Cagar Alam Gunung Sibela, menjadikan kawasan ini sangat menarik untuk dikaji.

Berdasarkan hasil penelitian lebih lanjut, Ahmad et al., (2015) memaparkan bahwa telah terdata berbagai jenis serangga. Secara rinci terdapat sebanyak 424 individu serangga yang terdata dibeberapa lokasi peneltian di Pulau Bacan dari 34 jenis kupu-kupu. Adanya berbagai jenis kupu-kupu di pulau Bacan dan sekitarnya, merupakan daya tarik tersendiri dan menambah eksotisme pada kawasan Cagar Alam Gunung Sibela.

Kupu-kupu di ekosistemnya berperan sebagai polinator dalam penyerbukan berbagai jenis bunga. Di sisi lain, kupu-kupu juga memberikan pesona dan keindahan pada alam dengan akulturasi warna pada tubuh dan sayapnya. Kupu-kupu sangat penting bagi keberlangsungan dan keseimbangan ekosistem, sehingga keberadaan kupu-kupu di alam menjadi salah satu indikator ekosistem. Penurunan jumlah populasi kupu-kupu di alam disebabkan oleh adanya alih fungsi hutan, penebangan liar, fragmentasi habitat, dan penangkapan liar. Salah satu cara untuk mempertahankan populasi kupu-kupu di alam adalah dengan melakukan eksplorasi jenis, sosialisasi kepada masyarakat, dan melakukan penangkaran.

Beberapa genus kupu-kupu yang terdapat di Gunung Sibela Pulau Bacan yakni Papilio, Ornithopthera, Troides dan Graphium. Keempat genus tersebut berasal dari family Papilionidae. Salah satu jenis kupukupu yang teridentifikasi yakni Papilio ulysses. Papilio Ulysses adalah salah satu jenis kupu-kupu yang paling terkenal, secara umum dikenal pula dengan sebutan kupukupu biru atau kaisar biru (blue emperor). Papilio ulysses merupakan bagian dari kelompok kupu-kupu peacock swallowtails dan merupakan genus Papilio subgenus Achillides F.L. (Condamine, et al., 2012). Secara khusus species Papilio ulysses merupakan kupu-kupu endemik di sekitar kepulauan Maluku, Papua, Solomon, sampai Benua Australia (Condamine, et al., 2012). Gambar morfologi dan dan peta penyebaran endemik kupu-kupu Papilio ulysses tergambar pada gambar 1 .

Kupu-kupu Papilio ulysses memiliki warna yang lebih menarik dibandingkan dengan jenis yang lainnya. Warna yang atratif dan mencolok tersebut menyebabkan kupu-kupu jenis ini menjadi buruan kolektor kupu-kupu.

Variasi yang luar biasa pada spesies ini menghasilkan banyak subspecies yang tersebar di daerah tersebut. Sampai saat ini, sebanyak 14 subspesies telah dikenali pada daerah penyebarannya (Braby 2000). Salah satu subspesiesnya ialah Papilio $u$. joesa, yang diakui sebagai subspecies endemik dengan penyebarannya yang terbatas di Australia serta jarang ditemukan (Sand dan New, 2002). Banyak dari spesies kupu-kupu yang 
tidak dimiliki datanya secara lengkap mulai dari penyebaran dan jumlah perkiraan individu dari tiap spesies secara rinci. Papilio ulysses juga merupakan salah satu speseis yang masih sangat kurang data keberadaan jumlah dan kelimpahannya. Kekurangan data ini dapat menimbulkan kerugian besar secara imateri karena kepunahan yang tidak terduga dapat saja terjadi seiring dengan perubahan iklim global.

Informasi mengenai kupu-kupu spesies $P$. ulysses secara morfologi dan variasinya masih terbatas dan kurang dalam publikasi oleh para peneliti lokal. Hal ini juga terjadi pada spesies lain dari genus Papilio. Salah satu publikasi oleh peneliti Indonesia mengenai spesis dari genus Papilio diantaranya ialah Papilio polytes oleh Makhzuni et al. (2013). Penelitian tersebut tentang variasi morfologi pada Papilio polytes dari beberapa lokasi yang berbeda di Sumatra Barat.

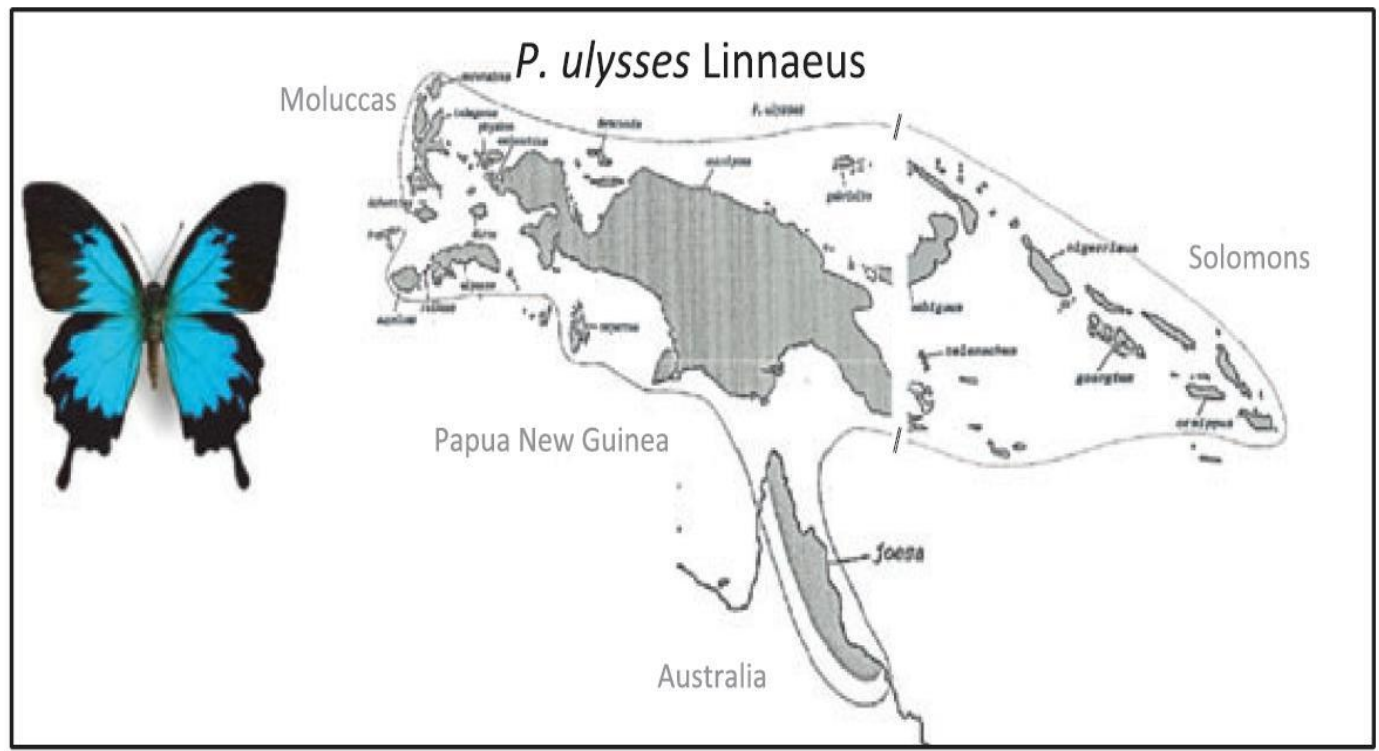

Gambar 1. Morfologi spesies Papilio ulysses dan peta penyebarannya meliputi Kepulauan Maluku, Papua, Solomon dan Australia (Condamine, et al., 2012).

Pada dasarnya data morfology dan data genetika dari makhluk hidup sama pentingnya. Keduanya dapat saling melengkapi dalam identifikasi, analisis kekerabatan dan keperluan taksonomi makhluk hidup. Ketersediaan data genetika dianggap lebih praktis dalam penyimpanan karena tidak memerlukan ruang yang luas dan dapat disimpan dalam bank gen (gene bank). Data genetika juga diperlukan dalam mengantisipasi ketiadaan data morfologi karena kelanggaan spesies atau spesies yang telah punah. Oleh karena itu diperlukan penelitian yang meliputi identifikasi, filogenetik, penyebaran, kelimpahan dan data ekologi Papilio ulysses. Penyediaan data genetik dapat dimulai dari data DNA barcode spesies makluk hidup.

DNA barcode merupakan urutan pasangan basa "base pair" (bp) pada genom yang umumnya pendek 
sekitar 650 bp (Hebert, et al., 2003). Pada kelompok Hewan, DNA barcode, biasanya menggunakan bagian dari genom mitokondria yakni gen cytochrome $c$ oxidase I (COI). Hal ini dikarenakan gen COI umumnya memiliki kemampuan mutasi yang relatif cepat, sehingga dapat membedakan sampel pada tingkatan taksonomi yang lebih rendah misalnya spesies atau individu (Burns, et al., 2007). DNA Mitokondria (mtDNA) telah digunakan secar umum di kalangan peneliti dalam bidang molekuler khususnya sebagai penanda molekuler filogenetik pada kelompok hewan khuusunya phypada. Hal ini juga disebabkan, mitokondria merupakan genom yang sangat sederhana. Urutan $m t D N A$ telah menyediakan data-data penting dalam menganalisis filogenetik, sehingga pemilihan gen sebagai penanda molekuler merupakan langkah yang sangat signifikan. Oleh karena itu, urutan DNA dari gen tertentu sangat penting untuk didapatkan. Dalam hal identifikasi, urutan DNA dapat digunakan untuk menguji atau memastikan bahwa spesies yang di dapat merupakan objek yang diteliti, dalam hal ini Papilio ulyses. Hasil penemuan ini akan menjadi dasar yang sangat penting bagi penelitianpenelitian kupu-kupu Papilio ulysses yang khusus endemik di Pulau Bacan.

Untuk menghasilkan sepasang primer spesifik bagi gen COI pada Papilio ulysses, maka diperlukan informasi mengenai sekuen gen meliputi lokasi gen dalam kromosom, panjang pasangan basa, dan informasi spesifik mengenai susunan dan persen basa pada gen tersebut. Kajian dan pengembangan informasi mengenai primer DNA yang spesifik untuk proses amplifikasi dengan metode Polymerase chain reactions (PCR) untuk gen COI pada Papilio ulysses endemik Pulau Bacan belum pernah dilakukan. Penyediaan primer berdasarkan desain primer spesifik sangat diperlukan untuk penelitian selanjutnya. Penelitian berupa penelusuran tentang informasi sekuen gen COI Papilio ulysses yang menghasilkan desain primer spesifik COI yang akurat perlu sangat perlu dilakukan. Penelitian ini bertujuan menghasilkan urutan primer spesifik COI pada Papilio ulysses dengan menggunakan perangkat lunak komputer (software).

\section{METODE}

\section{Penentuan DNA Template}

Penelitian ini merupakan penelitian berbasis in silico dalam mendesain primer PCR dengan menggunakan analisis bioinformatika. Pengambilan dan pengolahan data yang tersedia pada website penyedia gen dan layanan pengolahan/analisis gen dan DNA. Proses PCR (Polymerase Chain Reaction) memerlukan sepasang primer sebagai pemicu terbentuknya DNA baru yang mirip gen target seperti proses replikasi DNA (Handoyo dan Rudiretna, 2001).

Desain primer gen $\boldsymbol{C O I}$ dimulai dengan mengunduh sekuen DNA gen COI Papilio ulysses yang tersedia di GenBank. Gen dikopi dalam bentuk pasta (.txt) dan dijadikan acuan untuk mencari daerah lestari. Primer yang dibuat yakni primer untuk dua arah pembacaan DNA yakni primer forward (COI $\mathrm{Pu}-\mathrm{F})$ dan primer reverse (COI $\mathrm{Pu}$-R). Desain primer dibuat dengan ketentuan persen GC 
dari masing-masing primer harus di atas $50 \%$, perbedaan suhu mealting ideal antara kedua primer $\mathrm{F}$ dan $\mathrm{R}$ maksimal $4^{\circ} \mathrm{C}$. Panjang masingmasing primer berkisar antara 15 basa sampai 25 basa. Desain primer juga harus menghindari struktur sekunder dan primer dimer (Claverie, \& Notredame, 2007).

2. Desain primer gen $C O I$

DNA primer diharapkan dapat menempel pada bagian ujung kedua urutan gen COI. Hal ini agar primer menghasilkan panjang gen hasil amplifikasi yang maksimal. Setelah mengikuti aturan tersebut, selanjutnya primer akan didesain dengan menggunakan software primer designer yakni Genamics Expression (http://www.genamics.com/expressio n/order.htm). Urutan primer yang telah dihasilkan selanjutnya akan dapat di ujicoba atau dikonfirmasi secara insilico menggunakan perangkat lunak blast primer pada NCBI untuk mengetahui posisi akurat penempelan primer pada gen COI secara bioinformatika.

\section{HASIL DAN PEMBAHASAN}

1. DNA template sebagai cetakan primer

DNA template/cetakan yang dijadikan acuan pada desain primer adalah sekuen gen COI yang terdapat di genebank (http://www.ncbi.nlm. nih.gov) bersumber dari publikasi (Condamine, et al, 2012). Nomor aksesi Nukleotida: gi|331271451| gb| JF681034.1| Papilio ulysses voucher CBGPFLC_00362 cytochrome oxidase subunit I (COI) gene, mitochondrial. Sekuen secara lengkap adalah :

1 cgaaaatgac tttattcaac aaatcataaa gatattggaa cattatattt tatttttggt
61 atttgagcaa gaatattagg aacttcatta agtttattaa ttcgaactga attaggaacc

121 ccaggatctt taattggtga tgatcaaatt tataatacta ttgttacagc tcatgctttt

181 attataattt ttttatagt tataccaatt ataattggag gatttggaaa ttgattagtt

241 cctctgatat taggagctcc tgatatagct ttcccccgaa taaataatat aagattttga

301 ttattaccccctcattaacacttttaatt tca agaataa ttgtagaaaa tggagctgga

361 actggttgaactgtttatcccctctttca tc aaacattg cccatggaag aagatcagta

421 gacttagtta ttttctcett acatttagca ggtatttcct caattttagg agcaattaat

481 tttattacaa caattattaa tatacgtatt aataatatat catttgatca aataccttta

541 tttgtttgag ctgttggaat tactgcttta ttattacttc tttctttace agtcttagca

601 ggtgctatta ctatattatt aacagatcga aatttaaata catcttttt tgatcctgca

661 ggaggaggag atcctatttt atatc aac at ttattttgat tttttggtca tccagaagtt

721 tatattttaa ttttaccagg atttggaata atttctcata ttatttccca agaaagagga

781 aaaaaagaaa catttgggtg tttaggt at aatttatgctataataacaat tggattatta

841 ggatttattg tatgagctca tcatatattt a ctgttggca tagatactga tacacgagct

901 tattttacat cagcaacaat aattattgca gtacctacag gaattaaaat ttttagttga

961 ttagctactt tacacggaac ccaaattaat tacagaccat caattttatg aagattagga

1021 tttgtttttc ttttactgt aggaggatta actggagtaa ttttagcaaa ttcatcaatt

1081 gatgtaacet tacatgatac ttattatgta gtagctcact ttcattatgt tttatctata

1141 ggagctgttt ttgctattat aggaagattt attcattgat atcctttatt tactggactt

1201 tcattaaatt cttacttttt aaaaattcaa tttttacta tatttattgg agtaaattta

1261 acatttttcc ctcaacattt tttagga

2. Urutan DNA primer yang dihasilkan

DNA template selanjutnya digunakan sebagai master untuk menjadi acuan primer dengan 
software genamic expresion. dan primer dari dua arah seperti Pembentukan primer dapat Gambar 2.

digambarkan dengan ilustrasi DNA

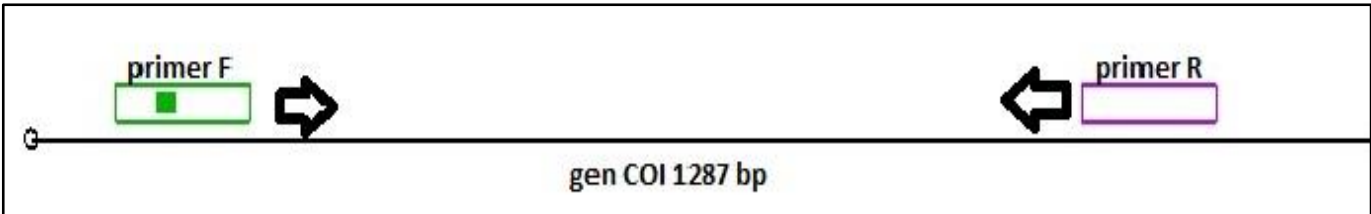

Gambar 2. Ilustrasi posisi primer Forward (F) dan primer Reverse (R) pada gen COI.

Primer forward dan reverse secara bersama dalam amplifikasi secara invitro akan menghasilkan urutan DNA COI parsial sepanjang 567 pasang basa. Penggunaan DNA parsial dalam pengenalan dan identifikasi jenis dapat dianggap sahih. Dalam analisis kekerabatan makhluk hidup penggunaan DNA parsial juga telah banyak dilakukan, diantaranya pada analisis filogenetik tanaman mangga (Suparman, Pancoro, dan Hidayat, 2013). Pada kelompok hewan, DNA Parsial khususnya gen COI juga umum digunakan dalam analisis molekuler misalnya pada hewan kelompok Hemiptera (Habeeb \& Sanjayan, 2011).

Pasangan primer hasil dari software genamic expression selanjutnya diujicoba dengan menggunakan fungsi blast primer yang ada pada NCBI. Fungsi blast ini merupakan simulasi secara insiliko yang menunjukan urutan DNA yang akan dihasilkan bila sepasang primer tersebut digunakan untuk amplifikasi pada saat proses PCR dengan mengikuti profil yang diseting sesuai dengan hasil desain primer tersebut. Simulasi tersebut akan mengenai target gen yang kita inginkan dalam hal ini gen COI Papilio ulysses jika data pada genebank telah tersedia gen yang dimaksud. Jika belum tersedia maka hasil blast primer akan mengenai gen yang lain yang cocok dan saling melengkapi dengan primer tersebut.

Hasil blast primer yang didapatkan dari fungsi blast primer NCBI dengan menggunakan primer hasil desain (COI PU-F dan $C O I P U$ R) tergambar pada Gambar 3. Sekuen gen COI yang akan didapatkan berdasarkan PCR menggunakan primer tersebut ialah parsial gen COI yang panjangnya 567 pasang basa dari 1287. Penggunaan sekuen gen yang tidak utuh pada beberapa kajian dapat dilakukan misalnya pada analisis keragaman, analisis filogenetik atau identifikasi jenis pada hewan

Hasil blast primer adalah hasil pencarian gen yang telah tersedia di genebank dengan aplikasi yang disediakan oleh website, dalam hal ini website NCBI. 
Desain Primer PCR secara In Silico 20

\begin{tabular}{|c|c|c|c|c|c|c|c|c|}
\hline \multicolumn{9}{|l|}{ Primer pair 1} \\
\hline & Sequence $\left(5^{\prime} \rightarrow 3^{\prime}\right)$ & Template strand & Length & Start St & Stop Tn & $\mathrm{Tm}$ & GC\% & Self complementarity \\
\hline Forward primer & CGAAAATGACTTTATTCAACA & Plus & 21 & 121 & 2150 & $50.74 \quad 28$ & 28.57 & 5.00 \\
\hline Reverse primer & AGCAGTAATTCCAACAGCTC & Minus & 20 & $567 \quad 54$ & $648 \quad 55$ & $55.74 \quad 45$ & 45.00 & 4.00 \\
\hline Product length & 567 & & & & & & & \\
\hline \multicolumn{9}{|c|}{ Products on intendad tarnet } \\
\hline & ucher CBGPFLC_00362 cytochrome & oxidase subunit I (COI) ge & e, partial cds & Is; mitochon & ndrial & & & \\
\hline \multicolumn{9}{|c|}{ product length $=567$} \\
\hline Forward primer & 1 CGAaAaTGaCTTTATTCAaCA 21 & & & & & & & \\
\hline Template & $1 \quad \ldots \ldots \ldots \ldots \ldots \ldots \ldots, 21$ & & & & & & & \\
\hline Reverse primer & 1 AGCAGTAATTCCAACAGCTO 20 & & & & & & & \\
\hline Template & $567, \ldots \ldots \ldots \ldots \ldots \ldots \ldots, \quad 548$ & & & & & & & \\
\hline \multicolumn{9}{|l|}{ Primer pair 2} \\
\hline & Sequence $\left(5^{\prime}>33^{\prime}\right)$ & Template strand & Length & h Start & Stop & $\mathrm{Tm}$ & GC\% & Self complementarity \\
\hline Forward primer & GACTTTATTCAACAAATCATAAAGA & Plus & 25 & 8 & 32 & 52.41 & 24.00 & 7.00 \\
\hline Reverse primer & ACCAGTTCCAGCTCCATTTT & Minus & 20 & 366 & 347 & 57.32 & 45.00 & 4.00 \\
\hline Product length & 359 & & & & & & & \\
\hline \multicolumn{9}{|c|}{ Products on intended target } \\
\hline$>$ F6681034.1 Papilio & Iysses voucher CBGPFLC_00362 cytochrome & oxidase subunit। (COI) ge & le, partial cds & s: mitochon & & & & \\
\hline
\end{tabular}

Gambar 3. Hasil blast primer pada website NCBI.

Prinsip kerja blast primer secara sederhana mirip dengan amplifikasi dengan metode PCR. Perinsip dasarnya yakni primer yang telah dibuat akan menempel pada potongan-potongan gen yang telah ada di genebank. Penggunaan blast primer ini merupakan simulasi apakah potongan primer yang telah didesain mengenai sasaran gen yang ditargetkan.

Temperature Melting yang didapatkan merupakan hasil kalkulasi yang direkomendasikan oleh aplikasi blast primer dalam NCBI. Suhu tersebut sedikit berbeda dengan yang direkomendasikan oleh hasil kalkulasi dari software DNA calculator pada www.biophp.org. TM untuk forward primer hasil DNA cacultaor adalah $47,7{ }^{\circ} \mathrm{C}$ dan untuk primer reverse
$52,8{ }^{\circ} \mathrm{C}$. Hasil ini menunjukan selisih sekitar $3-4^{\circ} \mathrm{C}$.

Pada hasil kalkulasi persen GC untuk masing-masing primer dengan menggunakan DNA calculator www.biophp yakni sekuen forward primer adalah 28,6 \% dan sekuen reverse primer adalah $45 \%$. Hal ini bahwa hasil kalkulasi persen GC dari NCBI dan biophp menunjukan kesamaan $100 \%$. Perbedaan dan kesamaan pada dua indikator dengan menggunakan aplikasi yang berbeda dan dari seumber yang berbeda dalam pembuatan primer secara insiliko akan mendapatkan hasil yang sedikit perbedaan. Berdasarkan hal tersebut, maka perlu dilakukan uji coba awal dalam melakukan amplifikasi secara invitro untuk mendapatkan sekuen gen target yang sesuai dalam PCR menggunakan mesin PCR. 
Tabel 1. Primer Forward dan Reverse (F dan R) yang didesain dengan software genamic expresion.

\begin{tabular}{|c|c|c|c|c|c|c|c|}
\hline \multicolumn{2}{|c|}{ Primer } & & $\begin{array}{l}\text { Panjang } \\
\text { Produk }\end{array}$ & & & $\begin{array}{l}\text { Struktur } \\
\text { Sekunder }\end{array}$ & Dimer \\
\hline $\begin{array}{l}\text { Forward } \\
(C O I P U-\mathrm{F})\end{array}$ & $\begin{array}{l}\text { CGAAAA } \\
\text { TGACTTT } \\
\text { ATTCAA } \\
\text { CA }\end{array}$ & 21 & 567 & 28,6 & 50,7 & NONE & NO \\
\hline $\begin{array}{c}\text { Reverse } \\
(C O I P U-\mathrm{R})\end{array}$ & $\begin{array}{l}\text { AGCAGT } \\
\text { AATTCC } \\
\text { AACAGC } \\
\text { TC }\end{array}$ & 20 & 567 & 45,0 & 55,7 & NONE & NO \\
\hline
\end{tabular}

*TM : Temperature Melting adalah suhu penempelan primer pada gen target.

Beberapa mesin PCR juga memiliki sensitifitas yang berbeda, sehingga secara umum kecocokan antara hasil kalkulasi apliksi secara insiliko dengan invitro terkadang terdapat perbedaan. Perbedaan ini biasanya dapat diatasi dengan percobaan awal PCR. Berdasarkan sekuen primer yang didesain dengan metode simulasi insiliko menggunakan blast primer pada NCBI, maka profil suhu prediksi amplifikasi gen COI untuk PCR dari genom kupu-kupu jenis Papilio ulysses diperkirakan sebagaimana tergambar dalam gambar 4.

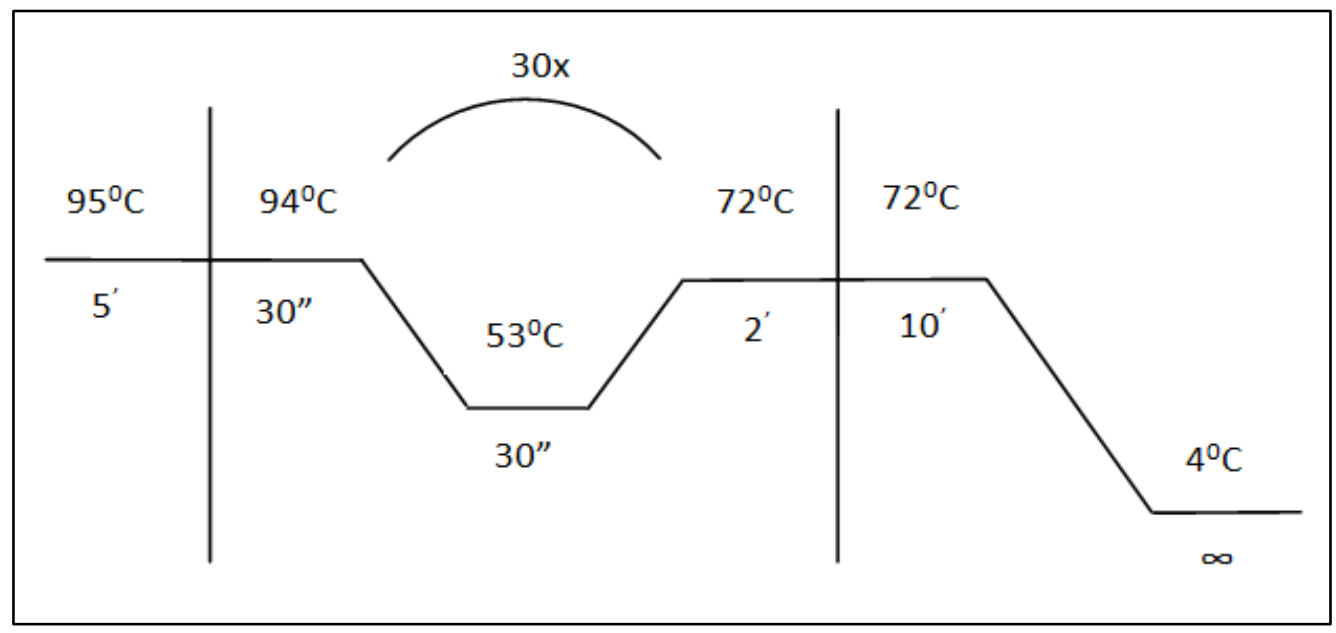

Gambar 4. Desain profil suhu amplifikasi primer COI pada gen target.

Profil suhu pada gambar 4 dapat diartikan yakni : tahap persiapan denaturasi pada suhu $95^{\circ} \mathrm{C}$ selama lima menit. Tahap denaturasi selama 30 detik pada suhu $95^{\circ} \mathrm{C}$ yang dilanjutkan dengan annealing pada suhu $53^{\circ} \mathrm{C}$ selama 30 detik. Tahap lanjutnya yakni pemanjangan hasil annaealing DNA selama 2 detik pada suhu $72^{\circ} \mathrm{C}$. Ketiga tahapan tersebut terjadi sebanyak $30 \mathrm{x}$ pengulangan yang dilanjutkan tahap akhir 
pemanjangan pada suhu $72^{\circ} \mathrm{C}$ selama 10 menit. Suhu akhir $4^{\circ} \mathrm{C}$ adalah suhu penyimpanan setelah amplifikasi selesai.

Pengulangan basa/repeats pada primer sebaiknya tidak memiliki urutan pengulangan dari 2 basa tetapi maksimum pengulangan 2 basa sebanyak 4 kali masih dapat ditoleransi. Misalnya ATATATAT. Primer juga sebaiknya tidak memiliki urutan basa yang diulang terus menerus. Pengulangan basa berurutan sampai 4 kali masih dapat ditoleransi. Misalnya AGCGGGGGATGGGG memiliki urutan basa $\mathrm{G}$ diulang 5 kali berturut-turut. Secara manual, suhu annealing optimum sangat mempengaruhi hasil PCR. Suhu Optimal (Ta Opt) ini dapat dihitung dengan cara Ta Opt $=0.3 \times(\mathrm{Tm}$ of primer $)+0.7 \times($ Tm of product $)-25$. Penggunaan profil suhu PCR yang didapatkan akan sedikit berbeda pada mesin yang berbeda. Hal ini umumnya terjadi karena sensitifitas mesin dan alat yang digunakan juga berbeda. Perbedaan penting umumnya terjadi pada suhu annealing.

3. Panjang produk hasil PCR dan suhu optimal

Panjang basa produk hasil PCR ialah 567 bp. Panjang basa produk DNA target gen $C O I$ yang dihasilkan merupakan gen parsial yakni hanya 567 bp dari 1287 bp gen target pada COI. Ini merupakan hasil terpanjang dibandingkan dengan primer lainnya. Suhu annealing optimal diprediksikan antara 50-55 64 derajat celsius. Gen COI khususnya sub unit I merupakan salah satu gen yang umum dijadikan sebagai markah genetik atau barkode khususnya pada kelompok hewan. Aka tetapi, pada awalnya para ahli juga mengunakan gen COI dalam rekonstruksi filogenetik pada tumbuhan, misalnya pada kelompok tumbuhan Araucariaceae (Setoguchi, et al., 1998) atau pada Angiospermae secara umum (Barrachlough, et al., 1996). Pada perkembangan selanjutnya, khusus pada tumbuhan digunakan penanda yang lebih spesifik pada genom kloroplas yakni gen $r b c \mathrm{~L}$, misalnya pada analisis filogenetik Genus Mangifera (Suparman, Pancoro, dan Hidayat 2013).

Dalam studi filogenetik molekuler, gen COI dapat digunakan dalam analisis karakteristik genetik antar dan intra spesies (Folmer, et al., 1994). Sekuen DNA barkode memegang peran tambahan yang penting dalam alur kerja taksonomi sehingga barkoding DNA tidak dapat tergantikan untuk analisis taksonomi yang menyeluruh (Hajibabaei, Singer \& Hickey, 2007). Sekuen DNA dari beberapa jenis tumbuhan atau dari beberapa spesiemen dapat digunakan untuk rekonstruksi dan analisis filogenetika. Filogenetika merupakan satu bagian yang penting dalam analisis taksonomi yang menyeluruh, karena menyediakan informasi kekerabatan berdasarkan sejarah evolusi gen dan jenis dari masingmasing sampel.

Primer gen COI yang telah dibuat selanjutnya akan digunakan dalam amplifikasi gen COI Papilio ulysess dari beberapa sampel. Hasil amplifikasi tersebut selanjutnya digunakan untuk rekonstruksi pohon filogenetik yang dapat memberikan informasi kekerabatan berdasarkan urutan DNA gen COI. Hal ini tentu membutuhkan keakuratan dalam mendesain dan menghasilkan primer 
gen $C O I$ sehingga menghasilkan produk PCR yang akurat.

4. Pemanfaatan sekuen DNA primer dan sekuen DNA COI

DNA primer sangat penting dalam rangkaian analisis DNA. Desain DNA primer merupakan langkah awal yang menentukan keberhasilan analisis DNA. Sekuen DNA primer akan digunakan dalam amplifikasi dengan metode PCR. Hasil sekuen gen yang didapatkan dapat dimanfaatkan dalam identifikasi spesies, taksonomy dan analisis kekerabatan.

Hasil sekuen DNA yang didapatkan pada jenis Papilio ulysses dari hasil PCR nantinya akan dapat digunakan sebagai pembanding dari data morfologi dalam indentifikasi jenis. Hal ini dikarenakan data morfology jenis kupu-kupu tersebut memiliki kesamaan yang tinggi dengan jenis lainnya berdasarkan pengamatan langsung. Dalam penelitian lebih lanjut, sekuen DNA gen COI Papilio ulysses yang dihasilkan dari proses PCR nanti dapat juga diajukan menjadi DNA barcode pada spesies tersebut.

Penyediaan sekuen DNA primer dalam konservasi genetik jenis makhluk hidup merupakan salah satu usaha konservasi secara tidak langsung dalam pelestarian jenis. Sekuen gen hasil amplifikasi dengan primer PCR yang baik akan menghasilkan sekuen gen yang akurat. Sekuen gen yang akan dihasilkan, dalam hal ini gen COI Papilio ulysses akan sangat membantu dalam usaha pelestarian dan konservasi jenis hewan endemik Pulau Bacan khsusunya bagi jenis kupu-kupu.

\section{SIMPULAN DAN SARAN}

Primer gen COI sub unit I pada kupu-kupu Papilio ulysses yang optimal ialah CGAAAATGACTT TATTCAACA untuk primer forward dan AGCAGTAATTCCAACAG CTC untuk primer reverse. Suhu optimal berdasarkan perhitungan DNA calculator ialah $50,74-55,74{ }^{\circ} \mathrm{C}$. Panjang Produk PCR yang diperkirakan ialah 567 bp.

\section{DAFTAR PUSTAKA}

Ahmad, H., Mas'ud, A., Ahmad, Z., 2015. Butterfly on the Island Bacan North Mollucas Province; How Density. International Journal of Engineering Research and Development. Volume 11, Issue 01:01-07

Barrachlough, T.G., Harvey, P.H., \& Nee, S. (1996) : Rate of COI gene sequences evolution and species diversification in flowering plants (Angiospermae). The Royal Society. Proc. R. Soc. Lond. B 263, 589-591.

BPS Halmahera Selatan. 2015. Halmahera Selatan Dalam Angka. Badan Pusat Statistik Kabupaten Halmahera Selatan.

Braby, M.F. (2000). Butterflies of Australia: Their Identification, Biology and Distribution. CSIRO Melbourne.

Burns, J.M., Janzen, D.H., Hajibabaei, M., Halwachs, W., \& Hebert, P. D. N., (2007). DNA Barcodes of Closely Related (But Morphologically

And Ecologically Distinct) Species Of Skipper Butterflies (Hesperiidae) 
Can Differ By Only One To Three Nucleotides. Journal of The Lepidopterists' Society : 61(3) :138-153

Claverie, J.M., \& Notredame, C. (2007) : Bioinformatics for Dummies $\quad 2^{\text {nd }}$ edition.Wiley Publishing, Inc. Indianapolis.

Condamine, F. L., Toussaint, E. F. A., Cotton, A.M., Genson, G.S., Sperling, F., A.H., Kergoat, G. J.,(2012) : Fine-scale biogeographical and temporal diversification processes of peacock swallowtails (Papilio subgenus Achillides) in the IndoAustralian Archipelago. Cladistics 1 : 1-24. 10.1111/j.10960031.2012.00412.x. The Willi Hennig Society.

Folmer, O., M. Black, W. Hoch, R. \& Lutzand R. Vrijenhoek. (1994). DNA primers for amplification ofmitochondrial cytochrom coxidase subunit I from diverse metazoan invertebates. Molecular Marine Biology \& Biotechnology 3(5):294-299.

Habeeb, S.K.M., \& Sanjayan, K.P., (2011). Sequencing And Phylogenetic Analysis Of The Mitochondrial Cytochrome C Oxidase Subunit I Of Xycarenus Laetus (Hemiptera: Lygaeidae). International Journal of Plant, Animal and Environmental Sciences, 1(3): 85-92

Hajibabaei, M., Singer, G.A.C., Hebert, P.D.N \& Hickey, D.A. (2007) : DNA barcoding: how it complements taxonomy, molecular phylogenetics and population genetics. Trends in Genetic.

Handoyo. D., dan Rudiretna. A.,(2001). Prinsip Umum dan Pelaksanaan Polymerase Chain Reaction (PCR).Unitas, 9(1): 1729.

Hebert, P.D.N., Cywinska, A., Ball, S.L., \& DeWaard, J.R., (2003). Biological identifications through DNA barcodes. Proc. Biol. Sci. 270: 313-321.

Makhzuni, R., Syaifullah \& Dahelm. 2013. Variasi Morfometri Papilio polytes L. (Lepidoptera: Papilionidae) di Beberapa Lokasi di Sumatera Barat. Jurnal Biologi Universitas Andalas (J. Bio. UA.) 2(1): 50-56.

Sands, D.P.A., \& New, T.R. (2002) The Action Plan for Australian Butterflies, Environment Australia, Canberra.

Setoguchi, H., Osawa, T.A., Pintaud, J.C., Jaffre, T. \& Veillon, J.M., (1998) : Phylogenetic Relationships within Araucariaceae Based on COI Gene Sequences, American Journal of Botany 85(11): 15071516.

Suparman, Pancoro, A., dan Hidayat, T., (2013). Phylogenetic Analysis of Mangifera base on $r b c L$ sequences, Chloroplast DNA. Scientific Papers-Series B, Horticulture. LVII: 235-240. 
25 Jurnal Pendidikan Matematika dan IPA Vol. 7. No. 1. Januari 2016: 14-24 